\title{
ČLÁNKY
}

\section{Zásada subsidiarity ve vztahu $k$ Úřadu evropského veřejného žalobce}

\section{Principle of Subsidiarity in Accordance with the European Public Prosecutor's Office}

\author{
Štěpán Kořínek ${ }^{*}$
}

\begin{abstract}
Abstrakt
Př́spèvek se zaobirá problematikou zásady subsidiarity ve vațabu k Úradu evropskébo veréejného žalobce (ÚEVŽ). Právě qásada subsidiarity predstavovala bodový zlom v procesu konstituováni ÚEVŽ́, který vedl až k současnému stavu prijetí ÚEVŽ na základě posilené spolupráce. Subsidiarita jako klićový právni princip hojnè prostupuje celou materii evropského práva, pričemž se samožrejmè dotýká jeho institutu (jako ÚEVŽ). Př̌spèvek je rozçlenèn do trech částí, kterým prèdcházi úvod a uzavírá závèr. První cuást se vènuje zásadè subsidiarity a jejímu charakteristickému vymez̨ní, pricem气̌ subsumuje teoretické definice pojmu subsidiarita, rĩzné védni př̌stupy, dílǔ aspek.ty zásady subsidiarity a samozrérjmé zásadu subsidiarity z. pobledu evropského práva. Drubá kapitola je sondou do drubého vidčího principu evropskébo práva - proporcionality jako komplementarity k subsidiaritě. Treti kapitola posléze reflektuje roz̧bodnou kauqu otázky narušeni subsidiarity prí konstituováni ÚEVŽ.
\end{abstract}

\section{Klíčová slova}

Evropský veŕejný žalobce; evropská prokuratura; Evropská unie; subsidiarita; princip subsidiarity.

\section{Abstract}

The contribution deals with a topic of the principle of subsidiarity in relation to the European Public Prosecutor's Office (EPPO). The principle of subsidiarity represents a point break in the process of establishing the EPPO, which leads to establishment the EPPO on the basis of enhanced cooperation. The key legal principle of subsidiarity is abundantly permeating the european law whereas is focusing on its institutes (as EPPO). The contribution is devided into three parts, preceded by introduction and closed by conclusion. The first part deals with the characteristics of the principle of subsidiarity. There are also theoretical definitions of subsidiarity, various science approaches, partial aspects of subsidiarity and the principle of subsidiarity in the field of the european law. The second section can be seen like a probe into the second leading principle of the european law - proportionality as a complementarity to subsidiarity. Afterwards the third part is reflecting the categorical case of violation of the principle of subsidiarity by establishing the EPPO.

\footnotetext{
* JUDr. Bc. Štěpán Kořínek, Filozofická fakulta, Masarykova univerzita, Brno; Právnická fakulta, Univerzita Karlova, Praha / Faculty of Arts, Masaryk University, Brno, Czech Republic; Faculty of Law, Charles University, Prague, Czech Republic / E-mail: sKorinek@seznam.cz; gmkorinek@gmail.com / ORCID: 0000-0002-3973-3805
} 


\section{Keywords}

European Public Prosecutor; European Prosecution; European Union; Subsidiarity; Principle of Subsidiarity.

\section{Úvod}

„S truk.tury, programy a plány Evropské unie musíme chápat tak, že existuji prostě pro sebe samé. Evropa nám predkládá novou variantu Descartesova výroku: ,Myslím, tedy jsem'; její verze zni: ,Jsem, tudiž konám" ". ${ }^{1}$ Margaret Thatcherová

Jedním z mnoha cílů EU je i posilování boje proti trestné činnosti a zefektivňování postihu kriminality obecně pro zajištění vyšší míry bezpečnosti a spravedlnosti v evropském prostoru. Evropská unie (dále jen „EU“) na sebe vzala toto břímě a garantuje ho uplatňovat $\mathrm{v}$ rámci prostoru svobody, bezpečnosti a práva. ${ }^{2}$ Zrrízení Úřadu evropského veřejného žalobce (dále jen „ÚEVŽ‘) může být proto považováno za jeden z mezních projektů v oblasti svobody, bezpečnosti a práva v EU. Zároveň se může jednat i o jisté náznaky fundamentálních změn v oblasti svobody, bezpečnosti a práva. ${ }^{3} \mathrm{~V}$ souvislosti s tématem tohoto př́spěvku je rozhodující prostor „práva“, jinými slovy tzv. justiční spolupráce v trestních věcech. ${ }^{4}$ Tato kooperace je založena na dvou vůdčích principech - zásadě vzájemného uznávání justičních rozhodnutí, harmonizaci právních předpisů např́č EU, ale i postihu protiprávního jednání ohrožujícího finanční zájmy EU. ${ }^{5}$ ÚEVŽ může předesílat i prvotní signál zásadnější mezní změny - první rozpačitý krok k federalizaci EU, či její centralizaci. ÚEVŽ vznikl jako požadavek zefektivnění ochrany finančních zájmů EU. Mnoho oficiálních zdrojů demonstruje skutečnost, že dochází k značným únikům z finančních zdrojů EU. Evropská komise několikrát upozorňovala na skutečnost, že ochrana unijních financí je nedostatečná, vymáhání práva je slabé, absentuje společná evropská politika evropského trestního stíhání a donucovací opatření jsou nerovnoměrně rozložená. ${ }^{6}$ Následné úniky jsou zpo̊sobeny dopadem kriminální činnosti (korupce, zpronevěra, podvody aj.), ale i nedbalým či nevhodným nakládáním s vynaloženými zdroji. Dosavadní mechanismy ochrany finančních zájmů EU se začaly jevit jako nedostatečné,

1 THATCHEROVÁ, M. Uméní vládnout. Praha: Prostor, 2003, s. 284.

2 Prostor svobody, bezpečnosti a práva nám reprezentuje oblast, ve které je garantován volný pohyb osob založený na občanském prvku, avšak při striktním dodržování ochrany základních lidských práv a svobod.

3 SPIEZIA, F. The European Public Prosecutor's Office. How to Implement the Relations with Eurojust? In: EUCRIM - The European Criminal Law Associations Forum, 2018, č. 2, s. 131.

4 Jedná se o sdílenou pravomoc EU, ve které vedle sebe participují členské státy a EU. Právě v této oblasti nachází své pevné místo i princip subsidiarity a proporcionality.

5 TOMÁŠEK, M. a kol. Právo Evropské unie. Praha: Leges, 2013, s. 349-359.

6 ZARIVNIJ, P. Správné načasování jako alfa omega pro zřízení a fungování Úřadu evropského veřejného žalobce. In: Státní zastupitelství, Wolters Kluwer, 2017, roč. 15, č. 1, s. 31. 
až přežité. Celý stav navíc podtrhává negativum, že celá unijní regulační mašinérie boje proti trestné činnosti dopadající na unijní zájmy působí na kaskádovitém charakteru. ${ }^{7}$ V tomto smyslu zastával ústřední postavení OLAF, alias Evropský úřad na boj proti podvodům. ${ }^{8}$ Tento orgán byl a je však nadán pouze $\mathrm{k}$ administrativnímu vyšetřování a nedisponuje prŕmými prostředky donucení. OLAF nemá postavení justiční autority trestní represe, proto ani nemůže iniciovat stíhání z vlastní vůle. ${ }^{9}$ Závěry jeho vyšetřování se pouze postupují príslušným vnitrostátním orgánům, které samy rozhodují o tom, jak s nimi naloží. Efekt těchto závěrečných výstupů většinou končí ve slepé uličce. Průměrně je datováno, že zhruba polovina zjištění vzešlých od OLAF vedlo k zahájení trestního stíhání. ${ }^{10}$ ÚEVŽ tak bude zcela novým přístupovým bodem k potírání trestné činnosti v EU.

Princip subsidiarity lze považovat za právně-politický koncept, který má za sebou dlouholetou genezi. Smyslem jeho zavedení pro oblast evropského práva se stala potreba regulace výkonu a dělby pravomocí mezi EU a členskými státy. Jak bude poukázáno níže, celá polemika osciluje kolem otázky legitimity činnosti EU, která má vykazovat co nejzdrženlivější tendence s co nejoptimálnější rozhodovací praxí. Korekce dělby pravomocí např́íc prohlubováním integrace EU je zcela zásadní, jak bude poukázáno i na vzájemný vztah vůči ÚEVŽ a zásadě subsidiarity. Princip subsidiarity se stal de iure základním nosným principem evropského práva inkorporací Maastrichtskou smlouvou. Revize v podobě Amsterodamské smlouvy přinesla připojení Protokolu o uplatňování zásad subsidiarity a proporcionality. ${ }^{11}$ Následující revize v podobě Lisabonské smlouvy pak posílily kontrolní mechanismy dodržování zásady subsidiarity.

\section{Princip subsidiarity - obecné konstituční vymezení}

V obecné doktrinálně teoretické rovině je subsidiarita vnímána jako právně-politický koncept s filozoficko-ideovými přesahy. Podíváme-li se na její čistě verbální význam zjistíme, že se jedná o právně-politický princip garantující, že obecnější jednotka bude podpůrně činná v situaci, kdy na řešení nepostačují výkonnostní premisy nižší jednotky. ${ }^{12}$ Flagrantně si lze demonstrovat, že tato komplementarita platí ve vztahu stát-samospráva

7 HERLIN-KARNELL, E. The Establishment of a European Public Prosecutor's Office: Between Better Regulation and Subsidiarity Concerns. In: GEELHOED, W. et al. Shifting Perspectives on the European Public Prosecutor's Office. Hague: T.M.C. Asser Press/Springer, 2018, č. 5, s. 45.

8 OLAF neboli „Office européen de lutte anti-fraude“.

9 MET-DOMESTICI, A. The Hybrid Architecture of the EPPO. From the Commission's Proposal to the Final Act. In: EUCRIM - The European Criminal Law Associations Forum, 2017, č. 3, s. 143.

10 KUHL, L. The European Public Prosecutor's Office - More Effective, Equivalent, and Independent Criminal Prosecution against Fraud? In: EUCRIM - The European Criminal Law Associations Forum, 2017, č. 3, s. 136 .

11 FUNTA, R., L. GOLOVKO a F. JURIŠ. Európa a európske právo. Bratislava: IRIS, 2016, s. 215.

12 KRAUS, J. et al. Nový akademický slovnik cizich slov A-Ž. Praha: Academia, 2008, s. 756. 
či Evropská unie-členské státy. Před delegací kompetencí na vyšší jednotku, jinak označováno za aktivizaci činnosti vyšších jednotek, se upřednostňuje činnost nižších jednotek. ${ }^{13}$ Větší jednotky organizující se v celky mají vždy tendence k vyšší míře centralizace, tedy extenzivnímu rozšiřování pravomocí nad ty, které jim byly uděleny primárně. ${ }^{14}$ Subsidiarita vystupuje jako opatření v protiakci nižších jednotek na narůstající míru centralizace, čehož je implikace decentralizace dělby pravomocí v EU. Pro celkové doplnění uvádíme, že v odborné literatuře se lze setkat s mnohými př́buznými definicemi pojmu subsidiarity. Jedním z paradigmat může být interpretace subsidiarity jako jednotlivých kroků, které mají být podnikány k dosažení př́íslušných met na nejvhodnější úrovni, $\mathrm{v}$ prrípadě pochybností však má být dána přednost nižším úrovním operacionalizace. ${ }^{15}$

Principy subsidiarity a proporcionality jsou vnímány jako základní zásady fungování EU při výkonu unijních pravomocí. Pojem subsidiarita pochází z dvou latinských implikací slov subsidium (podpora či pomoc) či subsidere (sedět pod něčím). ${ }^{16}$ Zásada subsidiarity jako normativní princip by ve své ryzí podstatě měla zajistit optimální a efektivní dělbu pravomocí mezi EU (nadnárodní úroveň) a členské státy (národní úroveň). ${ }^{17}$ De facto by měla představovat limity pro excesivní výkon pravomocí ze strany EU. Zásada subsidiarity odpovídá na otázku: „Kdo má jednat-EU, nebo členský stát?’،, přičemž se uplatňuje vyvratitelná domněnka primárního jednání členských států. ${ }^{18}$ Zásada subsidiarity představuje možnost prrímého jednání EU v oblastech, které nespadají do její výlučné pravomoci a pouze za předpokladu, že cílů zamýšlené činnosti nemůže být dosaženo uspokojivě členskými státy na úrovních ústřední, regionální či lokální, ale z důvodů rozsahu takové činnosti či jejích účinků, může být daného cíle lépe dosaženo na unijní úrovni. ${ }^{19}$ Negativně je zde vymezeno, že se nemůže jednat o výlučné pravomoci EU, nebot' by došlo k logickému paradoxu s povahou věci. Užití subsidiarity proto přichází v úvahu zejména u sdílených pravomocí. ${ }^{20}$ Soulad konání EU se zásadou subsidiarity musí tedy

13 DRULÁKOVÁ, R. Subsidiarita v Evropské unii: právní princip anebo uq̌itečný symbol? Praha: Oeconomica, 2010, s. 11.

14 GERLOCH, A. Možnosti uplatnění principu subsidiarity při výkonu veřejné moci. In: GEORGIEV, J. (ed.). Princip subsidiarity v právní teorii a praxi. Praha: CEVRO Institut, 2007, s. 43.

15 GRETSCHMANN, K. The Subsidiarity Principle: Who Is to Do What is an Integrated Europe. In: PAPPAS, S. (ed.). Subsidiarity: The Challenge of Change. Maastricht: EIPA, 1991, s. 50.

16 SCHEU, H. CH. Pojem a geneze principu subsidiarity. In: GEORGIEV, J. (ed.). Princip subsidiarity v právní teorii a praxi. Praha: CEVRO Institut, 2007, s. 16.

17 HORÁKOVÁ, M. Princip subsidiarity v právu EU. Diplomová práce. Brno: Právnická fakulta MU, 2015, s. 15.

18 SIMAN, M. a M. SLAŠŤAN. Právo Európskej únie. Bratislava: EUROIURIS, 2013, s. 87.

19 Čl. 5 odst. 3 SEU.

20 Podle určitých názorových proudo̊ není vyloučeno užití i pro podpůrné, koordinační nebo doplňující pravomoci EU viz SIMAN, M. a M. SLAŠŤAN. Právo Európskej únie. Bratislava: EUROIURIS, 2012, s. 87. Nicméně, jiné názory se uchylují k domněnkám, že působnost v rámci těchto pravomocí je vyloučena viz DRULÁKOVÁ, R. Subsidiarita v Lisabonské smlouvě - náprava nedostatkè? Praha: Oeconomica, 2009, s. 13. 
kumulativně splňovat tato kritéria - sledovaného cíle není možné dostatečně dosáhnout na vnitrostátní úrovni, a zároveň těchto cílů je možné lépe dosáhnout na unijní úrovni. Pokud však EU začne konat v př́padě, kdy má za to, že může vytýčených cílů dosáhnout snáze, tento svůj postoj musí prokázat v důvodové zprávě zamýšleného unijního aktu. Pro zásadu subsidiarity platí, že nedisponuje prrímým účinkem, nebot' vnitrostátní justiční orgány nemají dostatek pravomocí k vyhlášení aktu EU za neplatný z důvodu porušení této zásady. Tento prerogativ je vyhrazen pouze Soudnímu dvoru EU, jakožto představiteli soudní moci EU. ${ }^{21}$

Zásada subsidiarity tkví na kritériu komparativní účinnosti, což znamená eventualitu komparace všech prostředků a instrumentů vhodných $\mathrm{k}$ dosažení sledovaného cíle pro vyhodnocení jejich relativní účinnosti. Toto kritérium tak může být určující pro selekci konečného nástroje, který nejlépe odpovídá dosažení sledovaného cíle. Test komparativní účinnosti (comparative efficiency test) tkví v komparativní evaluaci nákladů a výnosů zamýšlených aktů a akcí mezi unijní a národní úrovní, přičemž ta unijní musí být efektivnější. ${ }^{22}$ Další kritérium se týká přidané hodnoty konání EU, kdy je zkoumán skutečný přínos jednání EU namísto jednání jednotlivých států. Je nutno dbát i vedlejších aspektů, zejména dodržování legislativního rámce $\mathrm{EU}$, hospodárnosti takového prostředku či konání, dbaní zřetele širších zájmů EU a jiné. ${ }^{23}$

Subsidiarita je tradičně pojímána jako vůdčí princip $\mathrm{k}$ výběru vhodné oblasti, ve které se má prosadit aktivní činnost EU namísto činnosti jednotlivých členských států. EU tak supluje aktivitu členského státu tím, že sama začne jednat. ${ }^{24}$ Zásada subsidiarity skýtá dvě generální dimenze. Jedna nám říká, že co už nestačí sama nižší jednotka efektivně vykonat, tak je činnost delegována na vyšší jednotku. Toto typicky odpovídá požadavkům na dosažení předeslaných cílů vhodněji na úrovni EU. Druhá nám signifikuje, že vyšší jednotky mají podporovat svojí činností nižší jednotky a tím přispívat $\mathrm{k}$ jejich hladkému fungování. Konotace intervenčního zásahu má v daném případě směřovat k posilování akceschopnosti nižších jednotek (členských států). Jedná se však o intervenční právo vyššího celku, nebo jeho povinnost? ${ }^{25}$ To si lze představit tak, že EU má podporovat a pomáhat členským státům v jejich aktivitách a činnostech pro dosažení cílů EU na národních úrovních. ${ }^{26}$ Podstatným znakem zůstává neustálá potřeba

21 SIMAN, M. a M. SLAŠŤAN. Súdny systém Európskej únie. Bratislava: EUROIURIS, 2012, s. 325.

22 HERLIN-KARNELL, E. The Establishment of a European Public Prosecutor's Office: Between Better Regulation and Subsidiarity Concerns. In: GEELHOED, W. et al. Shifting Perspectives on the European Public Prosecutor's Office. Hague: T.M.C. Asser Press/Springer, 2018, č. 5, s. 53.

23 SIMAN, M. a M. SLAŠŤAN. Právo Európskej únie. Bratislava: EUROIURIS, 2013, s. 88.

24 WIECZOREK, I. The Principle of Subsidiarity in EU Criminal Law. Cambridge: Hart Publishing, 2017.

25 DRULÁKOVÁ, R. Subsidiarita v Evropské unii: právní princip anebo ư̌itečný symbol? Praha: Oeconomica, 2010, s. $17-18$.

26 Ibid., s. 20 a násl. 
sledování dosažení proklamovaných cílů EU. Kontrola dodržování zásady subsidiarity je svěřena do pravomoci Soudního dvora EU v rámci řízení o neplatnosti aktu a vedle toho i národním parlamentům v rámci mechanismů ,žluté a oranžové karty“. Soudní dvůr však může slučitelnost unijních aktů se zásadou subsidiarity přezkoumávat výlučně a posteriori, tedy po nabytí platnosti unijního aktu. ${ }^{27}$

Unikátní se jeví mechanismus včasné výstrahy, přesněji tzv. „žluté a oranžové karty“. Ze strukturální povahy se jedná o inovaci začleněnou revizní Lisabonskou smlouvou. Podstata mechanismu spočívá v tom, že národní parlamenty jsou oprávněné k přezkumu návrhů legislativních aktů pro zjištění jejich (ne)souladu se zásadou subsidiarity ještě před přijetím takového aktu (kontrola ex ante). Stricto sensu se jedná o negativní přezkum zásady subsidiarity, který je vždy založen na konstatování ohledně shledání porušení principu subsidiarity. ${ }^{28}$ Exaktně mohou národní parlamenty do osmi týdnů předložit odůvodněné stanovisko $\mathrm{k}$ předloženému návrhu legislativního aktu a tím vymezit, $\mathrm{v}$ čem spatřují porušení zásady subsidiarity. ${ }^{29}$ Materiálně můžeme vyvodit tři pozitivní důvody přínosu mechanismu včasného varování. Zajisté posílení vymahatelnosti principu subsidiarity v evropském prostoru. Postupné snahy ke snižování demokratického deficitu EU a tím logickému posilování legitimity EU. Nakonec také zvyšování reprezentativnosti evropského legislativního procesu a jeho zkvalitňování. ${ }^{30}$ Více o těchto dvou mechanismech bude pojednáno dále.

Současné strukturální zařazení subsidiarity jako normativního principu komunitárního práva bylo provedeno Maastrichtskou smlouvou v roce 1992. Dnes je zásada subsidiarity jako vůdčí princip evropského práva zakotvena ve Smlouvě o Evropské unii (dále jen „SEU“), přesněji v její preambuli a čl. 5 odst. 3 SEU. Aplikační rozvedení upravuje Protokol č. 2 o používání zásad subsidiarity a proporcionality. Navíc, je explicitně doplněna využitelnost pro oblast svobody, bezpečnosti a práva, přesněji čl. 69 Smlouvy o fungování Evropské unie.

Primárním cílem zřízení ÚEVŽ je zabezpečit efektivnější ochranu finančních zájmů EU. Je více než jasné, že tohoto cíle může být lépe dosaženo na úrovni EU než jednotlivých členských států. ${ }^{31}$ Princip subsidiarity ve vztahu k ÚEVŽ je založen na nadnárodní povaze působnosti ÚEVŽ k povinnosti ochrany finančních zájmů EU. Subsidiarita nachází své uplatnění u prrípadů s transnacionálními aspekty, kdy není možné dosáhnout

27 PÍTROVÁ, L. Princip subsidiarity v EU - od virtuální reality k efektivní parlamentní kontrole. In: GEORGIEV, J. (ed.). Princip subsidiarity v právni teorii a praxi. Praha: CEVRO Institut, 2007, s. 107.

28 KIIVER, P. The Early Warning Systém for the Principle of Subsidiarity: Constitutional Theory and Empirical Reality. New York: Routledge Research in European Union Law, 2012, s. 33.

29 TICHÝ, L., R. ARNOLD, J. ZEMÁNEK, R. KRÁL a T. DUMBROVSKÝ. Evropské právo. 5. vyd. Praha: C. H. Beck, 2014, s. 216.

30 HORÁKOVÁ, M. Princip subsidiarity v právu EU. Diplomová práce. Brno: Právnická fakulta MU, 2015, s. 26.

31 POLT, P. Prokuratura Evropské unie - Úřad evropského veřejného žalobce. In: Státní zastupitelství, Wolters Kluwer, 2016, č. 5, s. 10. 
uspokojivé regulace na úrovni národní. ${ }^{32}$ Současné společenské struktury a mezinárodní vztahy jsou v EU, stejně tak jako ve světě, natolik komplikovanou záležitostí, že lze mít jednoznačně za to, že ochrana evropských hodnot a zájmů nemohla být nadále považována za dostačující výlučně na úrovni jednotlivých států. Intervenční snaha EU do posilování systému ochrany sociálních hodnot a zájmů je logickým krokem její existence. Podle nového programového směru EU zvaného „Better Regulation Agenda 2016“ tak EU prijímá alternativní akce v př́padě nedostatečnosti dosažení sledovaných cílů. ${ }^{33}$

\section{Zásada proporcionality - komplementární ohlédnutí}

Zásada proporcionality neboli přměřenosti nám říká, že obsah ani forma činnosti EU nepřekročí rámec toho, co je nezbytné pro dosažení cílů Unie. ${ }^{34}$ Elementární povahou jde o politicky ekonomický princip, nebot' aplikuje na právní i politické úkoly komparativní měřítko nákladů a výnosů. Proporcionalita nám tak vymezuje to, jakým způsobem má EU vykonávat své pravomoci, čím poskytuje odpověd’ na otázku: „V jakém rozsabu má EU konat? “ Taková opatření musejí být volena vždy s ohledem na sledovaný cíl, přičemž musejí vykazovat co možná nejmenší restrikce. ${ }^{35}$ Jedná se o explikaci proporcionality jako přiměřenosti prostředků k zamýšleným cílům. Přikládáme-li akcent jednomu sledovanému cíli, pak bychom nutně měli dbát co nejmenší míry znesnadnění dosahování dalších legitimních cílů. Konsekvence proporcionality říká, že pokud zakládající smlouvy EU výslovně neuvádějí požadavek na druh aktu pro daný případ, instituce EU smí vykonat výběr aktu právě na základě principu proporcionality. ${ }^{36}$

Proporcionalita vykazuje tři fundamenty, které tvoří její bázi. Racionalita jako vůbec první prvek proporcionality nám zavádí požadavek racionálního vztahu mezi nástroji a cíli. Proporcionalita tedy musí odpovídat rozumovému přesvědčení o vhodnosti zvoleného nástroje vzhledem na jasně vytyčené cíle. Druhý prvek je zastoupen užitečností, kdy náklady na využití nástroje a jeho udržování nesmějí převyšovat očekávané výnosy. Užitečnost je však zapotřebí posuzovat kauzálně, protože krátkodobé převýšení nákladů nemusí ještě nutně znamenat neprospěch oproti konečným pozitivům. Třetí element

32 GIUFFRIDA, F. Cross-Border Crimes and the European Public Prosecutor's Office. In: EUCRIM - The European Criminal Law Associations Forum, 2017, č. 3, s. 150.

33 „We (the EU) will be ambitious where we must, and modest wherever we can. Citizens across Europe expect the European Union to change... We have culled many rules, we have improved many others, and we have put forward proposals that focus on the big issues such as migration, security, investment and climate change. We will continue on this path listening to and acting on people's concerns. And if the Parliament and the Council take up our proposals and adopt them, real change will be felt by citizens all around Europe soon." State of the Union (2016). European Commission - Press release State of the Union 2016: Commission presents results of Better Regulation approach. Dostupné z: https://europa.eu/rapid/press-release_IP-16-3014_en.htm

34 Čl. 5 odst. 4 SEU.

35 SIMAN, M. a M. SLAŠŤAN. Právo Európskej únie. Bratislava: EUROIURIS, 2013, s. 90.

36 Čl. 296 SFEU. 
spočívá v minimalizování možné restrikce, nebot' selekce dostupného nástroje má vždy vyústit ve správnou volbu toho nejméně zatěžujícího. ${ }^{37}$ Všechny tyto složky jsou charakteristickými a neoddělitelnými součástmi principu proporcionality, které je nutno při jeho aplikaci pečlivě sledovat a neustále vyhodnocovat. Racionalita může být však chápána ještě jako užší vymezení rozumnosti (angl. reasonableness), která může být naopak uchopena jako modifikace právních argumentů v reakci na rozdílnost skutkových a kontextuálních okolností dané kauzy. Rozumnost potom musí kumulativně propojovat další tř́i dîlčí hodnoty - racionalitu, morálku a souladnost. ${ }^{38}$

Doposud nebyla věnována obecná pozornost pojmu „proporcionalita“ neboli přiměřenost. Proporcionalita vychází z latinského pojmu „pro portio“, který značí jistý vztah či poměr mezi dvěma a více prvky na základě předem známých a konstantních kritérií. Úvahy o principu proporcionality jakožto regulující (právnî) ideje vykazující axiologický charakter se začaly objevovat od nepaměti. Dnes bývá základ principu proporcionality vymezován jako ustálená doktrína vyžadující, aby inherentní činnost byla přizpůsobena cílům, které tato činnost sleduje. ${ }^{39}$ Takový zásah přitom bývá podmíněn tzv. testem proporcionality, který sestává ze třech složek - vhodnosti, potřebnosti a poměřování (komparace).$^{40}$ Toto samozrejmě platí i pro oblast evropského práva, byt' v modifikované podobě. Proporcionalita však zaujímá pevnější místo oproti subsidiaritě, což je dáno tím, že stála jako obecná právní zásada evropského práva mnohem dříve (zhruba od 60. let minulého stoletî). Zásada proporcionality také po obsahové stránce přesahuje rámec zásady subsidiarity, když totiž poskytuje ochranu základním právům jednotlivců. To jest dáno tak, že EU je nucena volit taková opatření, která zasahují do garantovaných práv a svobod jednotlivců co možná nejméně.

\section{Kauza subsidiarity $\mathrm{v}$ případě zavádění Úřadu evropského veřejného žalobce}

Zásada subsidiarity bývá využívána $\mathrm{v}$ rámci sdílených pravomocí EU, aby přitom nedošlo k oslabení národního prvku na podílení se na daných pravomocích, je stanoven balanční mechanismus. Uplatňování zásady subsidiarity je spojeno s posílením kontrolní úlohy vnitrostátních parlamentů členských států. ${ }^{41}$ Vnitrostátní parlamenty mají za úkol aktivně přispívat k řádnému fungování EU tak, že zajišt'ují dodržování zásady subsidiarity. ${ }^{42}$ Parlamenty

37 NEŠPOR, M. Principy subsidiarity a proporcionality v evropském právu. Diplomová práce. Brno: Právnická fakulta MU, 2006, s. 9-10.

38 ONDŘEJEK, P. Princip proporcionality a jeho role př interpretaci základních práv a svobod. Praha: Leges, 2012, s. 29-30.

39 Ibid., s. 23.

40 FUNTA, R., L. GOLOVKO a F. JURIŠ. Európa a európske právo. Bratislava: IRIS, 2016, s. 216-217.

41 TOMÁŠEK, M. a kol. Právo Europské unie. Praha: Leges, 2013, s. 157.

42 Čl. 12 písm. b) SEU a čl. 69 a 352 odst. 2 SFEU. 
členských států jsou oprávněny posoudit legitimitu navrženého legislativního aktu z hlediska zachování vlastní suverenity a vhodnosti ustanovení. ${ }^{43}$ Princip subsidiarity vykazuje jakýsi kvazi-moderační potenciál, čímž vlastně vylučuje absolutní suverenitu jednoho útvaru. ${ }^{44}$ Parlamenty vlastně vykonávají jakýsi dozor a ochranu nad uplatňováním zásady subsidiarity ze strany EU v rámci sdílených pravomocí, přičemž dbají toho, aby EU zbytečně nepřekračovala svoji působnost a stanovené cíle. ${ }^{45} \mathrm{EU}$ by ani neměla vměšovat do prerogativů členských států nadmíru nezbytné potřebě dosažení stanovených cílů a v mezích překračujících princip subsidiarity. ${ }^{46}$ Vlastní kontrolní oprávnění spočívá v tom, že je vnitrostátním parlamentům umožněno do osmi týdnů obrátit se na představitele unijních orgánů a institucí (Evropského parlamentu, Rady a Komise) s odůvodněným stanoviskem, že předložený návrh legislativního aktu je nebo může být v rozporu s principem subsidiarity. ${ }^{47}$

$\mathrm{V}$ př́padě, kdy nejméně třetina parlamentů předloží takové stanovisko vưči předloženému návrhu Evropské komise, ta musí tento návrh přezkoumat. Komise má nadále tři možnosti, bud'to rozhodne o tom, že návrh ponechá nezměněný, pozmění jej, nebo jej vezme zpět. Procesní rozhodnutí Komise musí být řádně odůvodněno. Tento mechanismus se nazývá ,žlutá karta“ a jedná se vlastně o jakési předběžné varování uplatnitelné z počátku legislativního procesu. Tento mechanismus je doplněn silnějším kontrolním postupem pro př́pad, že Komise setrvá na projednání daného návrhu, i když se proti němu vyslovila nadpoloviční většina parlamentů. Jedná se o mechanismus „oranžové karty“. Vyjádření Komise i stanoviska parlamentů se předkládají zbylým evropským institucím (Evropskému parlamentu a Radě), aby konstatovaly svoje stanovisko návrhu vưči zásadě subsidiarity. Tyto dva orgány pak rozhodují specifickým a poměrně náročným způsobem. Podstatou mechanismu „oranžové karty“ je jeho uplatnitelnost pouze $\mathrm{v}$ rámci řádného legislativního procesu. No a celý kontrolní systém je doplněn i mechanismem „červené karty ${ }^{\text {“48 }}$, který představuje možnost zcela zablokovat změnu legislativního postupu v prrípadě využití zvláštní přechodové klauzule o přechodu od jednomyslnosti v Radě k řádnému legislativnímu postupu. ${ }^{49}$ Oba zmíněné kontrolní mechanismy „žluté i oranžové karty“ jsou inherentní ke kumulativnosti procedury, když totiž jejich

43 POLT, P. Prokuratura Evropské unie - Úřad evropského veřejného žalobce. In: Státni zastupitelství, Wolters Kluwer, 2016, č. 5, s. 12.

44 NEŠPOR, M. Principy subsidiarity a proporcionality v evropském právu. Diplomová práce. Brno: Právnická fakulta MU, 2006, s. 11.

45 TICHÝ, L., R. ARNOLD, J. ZEMÁNEK, R. KRÁL a T. DUMBROVSKÝ. Evropsképrávo. 5. vyd. Praha: C. H. Beck, 2014, s. 215.

46 ZWIERS, M. W. The European Public Prosecutor's Office. Analysis of a Multilevel Criminal Justice Systém. Cambridge - Antwerp - Portland: Intersentia, 2011, s. 10.

47 Čl. 6 a 7 Protokolu č. 2 o používání zásad subsidiarity a proporcionality.

48 Vznikají však tzv. mrtvé instituty, které nedojdou svého naplnění. Více viz GRINC, J. Národníparlamenty a demokratická legitimita Evropské unie. Praha: Leges, 2015, s. 192.

49 TOMÁŠEK, M. a kol. Právo Evropské unie. Praha: Leges, 2013, s. 158. 
aktivace je závislá od počtu předložených odůvodněných stanovisek. No a právě mechanismus ,žluté karty“ byl využit v prípadě původního návrhu Komise na zř́zení ÚEVŽ.$^{50}$ Evropská komise se rozhodla ke dni 17. 7. 2013 na základě příslušných ustanovení čl. 86 SFEU a čl. 325 SFEU předložit návrh nařízení o zř́izení ÚEVŽ. ${ }^{51}$ Tento svůj úmysl odůvodnila potřebou zefektivnění ochrany finančních zájmů EU, protože spatřovala, že justiční orgány členských států nebyly schopny rovnocenně chránit zájmy EU a jednotně vymáhat právo. ${ }^{52} \mathrm{Z}$ tohoto důvodu bylo proklamováno, že je EU povinna i oprávněna jednat a přijmout adekvátní akty. Předložený návrh byl vlastně takový balík nových opatření, který se zaměřoval na několik úskalí. Nejprve na zlepšení ochrany finančních zájmů EU, na vytvoření ÚEVŽ, reformování Eurojustu či modernizování OLAF. ${ }^{53}$ Ve stejném roce však Výbor pro evropské záležitosti při mad’arském parlamentu shledal porušení zásady subsidiarity předloženým návrhem nařízení o ÚEVŽ. Mad'arsko bylo od počátku snah o zavedení ÚEVŽ poměrně skeptické a zdrženlivé. Negativní stanovisko Mad'arska operovalo s premisou toho, že bylo možné požadovaných cílů dosáhnout i jinými prostředky než zavedením specifického orgánu veřejné žaloby. ${ }^{54} \mathrm{Ne}$ jenom tím byla návrhu na zřízení ÚEVŽ dána ,žlutá karta“, čímž bylo požadováno jeho přezkoumání a uvedení do souladu podle vzešlých připomínek. ${ }^{55}$ Komise se však nechala slyšet s tím, že návrh spatřuje souladný se zásadou subsidiarity. Přičemž se odvolávala i na důvodovou zprávu $\mathrm{k}$ návrhu nařízení o ÚEVŽ a jeho finanční plán. Jednoznačně však odmítla tvrzení dostatečnosti stávajících nástrojů (OLAF, Eurojust a Europol). ${ }^{56}$ Nicméně, i tak se nechala slyšet, že zohlední došlá stanoviska národních parlamentů. ${ }^{57}$

Následně došlo v roce 2014 za řeckého předsednictví k předložení nového pozměněného návrhu na zřízení ÚEVŽ, který se značně odlišoval od toho původního. Prvotní prerokování návrhu o zřízení ÚEVŽ proběhlo 12. 3. 2014 a obsahovalo mnoho dílčích obměn.

50 MITSILEGAS, V. EU Criminal Law after Lisbon. Rights, Trust and the Transformation of Justice in Europe. Oxford - Portland - Oregon: Hart Publishing, 2016, s. 41.

51 Návrh byl představen formou oznámení „Lepši ochrana finančních zájmù Unie: vytvořni Úradu evropskébo veřejnébo žalobce a reforma Eurojustu" pod označením COM (2013) 532 Final.

52 POLT, P. Prokuratura Evropské unie - Úřad evropského veřejného žalobce. In: Státní zastupitelství, Wolters Kluwer, 2016, č. 5, s. 10-11.

53 ONDREJOVÁ, A. Európsky prokurátor. Komentár k nariadeniu Rady Európskej únie. Bratislava: Wolters Kluwer, 2017, s. 29-30.

54 Zejména argumentovalo možností využití evropského vyšetřovacího příkazu, posílení dalších stávajících nástrojů justiční spolupráce v trestních věcech, posílením vnitrostátních justičních orgánů či jinými způsoby.

55 Podáno devatenáct (19) negativních hlasů od čtrnácti (14) národních komor parlamentů České republiky, Francie, Irska, Kypru, Mad’arska, Malty, Nizozemska, Rumunska, Slovinska, Švédska a Velké Británie.

56 GŘIVNA, T. European public prosecutor. In: PÍTROVÁ, L. (ed.). Rule of Law and Mechanisms of its Protection - Czech Perspective. Passau: rw \& w Science \& New Media, 2015, s. 342-343.

57 ZARIVNIJ, P. Správné načasování jako alfa omega pro zřízení a fungování Úřadu evropského veřejného žalobce. In: Státní qastupitelství, Wolters Kluwer, 2017, roč. 15, č. 1, s. 29. 
Změny se dotkly především strukturální podoby Úřadu za sledování výhledu oslabení Úřadu a posílení postavení suverenit členských států. Strukturálně byl začleněn nový orgán kolegium jako vrcholný orgán ÚEVŽ s důrazem na posílení postavení a vlivu členských států. Úřad byl koncipován jako decentralizovaný s vlastní subjektivitou. ${ }^{58}$ Následovaly další změny předsednictví, tentokrát nastoupilo italské a lotyšské předsednictví. V této epoše došlo k obecnému zpřesnění kompetenčního rámce ÚEVŽ, za souběžné nevyvážené konsolidace ku prospěchu členských států. Druhotné prerokování proběhlo ke dni 29. 4.2015 a neustále si žádalo větší detailizaci jednotlivých kompetencí, vymezení jasné nezávislosti, dořešení strukturální podoby či vyjasnění procesních stránek vyšetřovací činnosti. ${ }^{59}$

Čas neúprosně plynul a předsednictva se stř́dala. Další v pořadí stanulo předsednictvo luxemburské a holandské. Neustále pokračovaly práce na textu nařízení o ÚEVŽ, zejména v podobě konkretizací, přepracování, diskuzí ohledně portfolia působnosti či kupříkladu otázky spojené s potřebou harmonizace dosavadních právních předpisů. Probíhaly proto nepřetržité konsolidace znění, revize textů, připomínkové dodatky a jiné formy doplňování a zpřesňování. Dokonce byl nadhozen i potenciální konflikt vztahu ÚEVŽ a extradičního mechanismu, potažmo i k evropskému zatýkacímu rozkazu. ${ }^{60}$ Následovalo slovenské předsednictví, které znamenalo zvrat v přístupu k ÚEVŽ. Nejenom, že bylo vyvoláno několik živých debat, ale především se dbalo na to, aby tyto debaty skutečně prrispěly k nějakému žádoucímu posunu. V průběhu slovenského předsednictví proto došlo k široké koncepční shodě a účelnému kompromisu pro přijetí návrhu na zřízení ÚEVŽ. Jedním z mnoha představitelů, kteří se zasloužili o takový pozitivní vývoj, byla Anna Ondrejová, toho času prokurátorka Generální prokuratury Slovenské republiky, která se po několik let usilovně věnovala problematice vytváření Evropské prokuratury ze strany Slovenska.

Počátek roku 2017 byl směrodatný pro další osud ÚEVŽ.V tomto roce přišlo na řadu maltské a estonské předsednictví, které nebylo schopné dosáhnout jednomyslnosti přijetí návrhu o zřízení ÚEVŽ. Na základě těchto událostí vyvstala hrozba toho, že zřízení ÚEVŽ opět upadne na nějakou dobu v zapomnění. To však vzbudilo nebývalý zájem skupiny členských států, které se rozhodly pokračovat v započaté integraci a navázat spolupráci v oblasti trestní jurisdikce mezi sebou. Př́hodně se jim nabízela varianta navázání posílené spolupráce za účelem zřízení ÚEVŽ. V první polovině roku 2017 proto probíhaly poslední úpravy a změny samotného textu nařízení o ÚEVŽ. V souvislosti se vznikem ÚEVŽ formou posílené spolupráce bylo nutné přispět k celkové stabilitě všech relevancí. Diskuzním fórem např́iklad prošla otázka vyrovnání se v podobě vyrovnávajícího prríspěvku pro neparticipující státy tak, aby tyto nedošly újmy vzhledem na fiskální rozkolísání a ekonomickou nerovnováhu jednotlivých členských států (rozdílnost

58 ONDREJOVÁ, A. Európsky prokurátor. Komentár k nariadeniu Rady Európskej únie. Bratislava: Wolters Kluwer, 2017, s. 36-40.

59 Ibid., s. 49-50.

60 Ibid., s. 52-57. 
hrubého domácí produktu). ${ }^{61} \mathrm{~V}$ druhé polovině roku 2017 se poté hovoří o finalizování textu nařízení o ÚEVŽ a konečném legislativním procesu, který probíhal v průběhu září. Dne 12. 10. 2017 je pak Radou přijato nařízení 2017/1939, kterým se provádí posílená spolupráce za účelem zrŕzení Úřadu evropského veřejného žalobce.

\section{Závěr}

Zásada subsidiarity i zásada proporcionality stojí vedle sebe v právním řádu EU jako sestry. Zásada subsidiarity představuje dynamický prvek při vykonávání pravomocí EU a členských států, zejména tedy těch sdílených. EU převezme výkon pravomocí jen tehdy, pokud to vyžadují konkrétní okolnosti a sledované cíle, a to pouze v míře nezbytně nutné pro dosažení takových cílů. Subsidiarita je tudíž korekcí dělby pravomocí v EU. Jednoznačně se přikláníme k názoru, že princip subsidiarity přispěl k prohlubování evropské integrace. Navíc, bylo představeno, že se jedná o poměrně letitý institut, který se axiologicky ustálil v právním rámci EU. Subsidiarita je obklopena demokratickým étosem, což také přispívá k upevnění postavení ÚEVŽ na bázi posílené spolupráce. Princip subsidiarity i proporcionality skvěle dotváři design ÚEVŽ zejména tím, že činnost Úřadu musí být v souladu s oběma principy. ÚEVŽ k tomu musí plně respektovat i fundamentální národní politické a ústavní struktury členských států, k čemuž napomáhá právě souladný postup s oběma zmíněnými principy. ${ }^{62}$ Lze mít také za to, že efektivní kontrola dodržování zásady subsidiarity členskými státy má pozitivní potenciál k přspění rádného fungování EU, nebot' zachování zásady subsidiarity je podmínkou legality unijní činnosti. ${ }^{63}$

Zásada subsidiarity bývá tradičně vnímána jako kontrakční opatření proti všemožným formám centralizačních tendencí. Tato asanační formule potom vystupuje jako garant zachování národní i regionální identity a suverenity. ${ }^{64}$ Ovace nad uplatňováním subsidiarity se však ozývají převážně z politických kruhů, kdežto část právnické obce devalvuje hodnotu subsidiarity tvrzením, že filozoficko-sociologický koncept není možné zdárně aplikovat v právu. Subsidiarita si ovšem zaslouží pozitivnější vnímání, nebot' se nejedná o pouhý strohý přístup k uspořádání vztahů v jedné organizaci (třeba EU), ale proniká hlouběji až k lidské společnosti, idejím státností a mezihodnotovým vztahům (autorita-svoboda). ${ }^{65}$ Idea tak stojí na respektování složitosti interní organizace lidské společnosti na úrovni státní, ale i širší unijní.

61 ONDREJOVÁ, A. Európsky prokurátor. Komentár k nariadeniu Rady Európskej únie. Bratislava: Wolters Kluwer, 2017, s. 71-75.

62 ZWIERS, M. W. The European Public Prosecutor's Office. Analysis of a Multilevel Criminal Justice Systém. Cambridge - Antwerp - Portland: Intersentia, 2011, s. 11-12.

63 BŘICHÁČEK, T. Unie blíkeá i vzdálená. Praha: Institut Václava Klause, 2014, č. 11, s. 47.

64 SCHEU, H. CH. Pojem a geneze principu subsidiarity. In: GEORGIEV, J. (ed.). Princip subsidiarity vprávní teorii a praxi. Praha: CEVRO Institut, 2007, s. 15.

65 ŠABATKA, M. Filosofická východiska principu subsidiarity. In: GEORGIEV, J. (ed.). Princip subsidiarity v právni teorii a praxi. Praha: CEVRO Institut, 2007, s. 25. 
Veřejná moc musí být opřena o demokratickou legitimitu lidu. Toto pravidlo platí pro všechny jednotlivé stupně veřejné moci, mezi které můžeme řadit i stát či útvar jako EU. Legitimita EU je ovšem takovým tvrdým ořǐšem, protože je odvozena od národních států jako hybatelů integračního procesu, avšak při absenci konzistentního politického národa evropského. Legitimita EU se proto vyznačuje dichotomickou povahou. ${ }^{66}$ Pokojné a fungující rozložení politických a právních poměrů musí plně respektovat jak princip subsidiarity, tak ale i princip demokratické legitimity. Jak prríhodně uvádí Jan Wintr, je třeba mít na paměti, že výstavba veřejné moci podle principu subsidiarity s sebou př́náší i rozličné problémy jako kompetenční konflikty (kdo je kompetenční k jednání - státy nebo EU?) nebo problém demokratického deficitu. Strukturální začlenění subsidiarity a jejich aplikačních procesů a kontrolních mechanismů však má tyto rizika eliminovat. Z empirických poznatků však lze dovodit, že evropské instituce vnímají zásadu subsidiarity spíše jako překážku na cestě k další hlubší integraci. ${ }^{67}$

Zásada subsidiarity představuje ve své nejryzejší podobě institucionální základ federativních soustátí, tedy federací. ${ }^{68}$ Od počátku integračního procesu se EU snaží upevňovat svoji legitimitu a celkové postavení, což mnozí označují za ambice k federalizaci. EU bývá označována jako integrační nástroj evropských zemí. ${ }^{69}$ Poslední revize primárního práva provedená Lisabonskou smlouvou jenom více ustálila supranacionální znaky tohoto integračního procesu. Polemika vzrůstá s názorem, že federalizaci urychluje zvyšování demokratické legitimity supranacionálních entit, jakou je právě i EU. Podle vyhraněného názoru tohoto myšlenkového proudu tak Lisabonská smlouva pouze jen učinila další krok k federalizaci EU tím, že právě navýšila její demokratickou legitimitu. ${ }^{70}$ Nebylo by namístě opomenout i euroskeptické postoje a názorové spektrum ve výhledu ontologie EU. Zastánci těchto směrů argumentují např́klad tím, že subsidiarita je jen abstrakcí politicky ohebného apelu, jehož hmatatelná normativnost je jen vágní floskuli. ${ }^{71}$ Zůstává pravdou, že i SD EU dříve označoval subsidiaritu za politický nástroj, přičemž avizoval, že jí bude přihlížet a postihovat jen ty nejzjevnější pochybení při uvážení evropského normotvůrce. ${ }^{72}$ Podle těchto názorů se jednalo jen o pouhý obraz povrchního a značně laxního prŕístupu evropské soudní instance vưči evropskému normotvůrci,

66 CABADA, L. et al. Aktuálni výzvy evropského integračního procesu. Plzeň: Aleš Čeněk, 2010, s. 79-80.

67 GRINC, J. Národni parlamenty a demokratická legitimita Evropské unie. Praha: Leges, 2015, s. 191.

68 FUNTA, R., L. GOLOVKO a F. JURIŠ. Európa a európske právo. Bratislava: IRIS, 2016, s. 216.

69 TÝ $\mathrm{C}, \mathrm{V}$. Enhanced cooperation and international treaties between member states as the possible means for overcoming the increased heterogenity of the European Union. In: ŠIŠKOVÁ, N. (ed.). The European Union - What is next? Köln: Wolters Kluwer, 2018, s. 211.

70 HAMULÁK, O. Integrujici se Evropa a suverenita Ceské republiky. Olomouc: AIO, Univerzita Palackého, 2013, s. 32-33.

71 BŘICHÁČEK, T. Unie blį́ká i vz̧dálená. Praha: Institut Václava Klause, 2014, č. 11, s. 51-52.

72 Rozsudek ESD z roku 1996, ve věci UK vs. Rada, č. C-84/94. 
z něhož čiší vysoká míra benevolence. ${ }^{73}$ Tato shovívavost potom deklaruje tendence evropských institucí a orgánů o vzájemnou oporu a sebeposilování, čímž vlastně posilují samotné postavení EU. Jejich názor se však opírá i o aplikační zkušenosti, kde totiž panuje přesvědčení, že rozhodnutí ponechat subsidiaritu jako nepřesně vyjádřený pojem v konečném důsledku znamenalo přenechání její aplikace a kontroly plně v režii unijních institucí. Subsidiarita je tak těmito euroskeptiky vnímána jako záměrně předhozený trojský kủň či časovaná bomba, která je aktivována na adekvátní okamžik. K tomu dodávají, že proporcionalita je ještě daleko abstraktnějším pojmem než subsidiarita a obě tyto zásady představují jakousi výbušnou směs, která může skončit katastrofou v podobě neřízené centralizační exploze, tedy vlastně tlakovou vlnou postupné federalizace. ${ }^{74}$

Pro závěrečné shrnutí uvádíme následující chápání, totiž, princip proporcionality slouží jako ochrana občanů (i občanů EU) před extenzivním rozšířením regulace na všech úrovních, kdežto princip subsidiarity se tváří jako garance optimální dělby pravomocí mezi nižší jednotky (členské státy) a vyšší jednotky (EU). ${ }^{75}$ Zásada subsidiarity brání uzurpování kompetencí v oblastech sdílených a podpůrných pravomocí a procesu vyprazdňování z národních úrovní. ${ }^{76}$ Subsidiarita je tedy kritériem demokracie, protože slouží jako záruka respektování národní diverzity v EU. Snahy o zmírňování nebo odstraňování demokratického deficitu při EU a tím posilování legitimity EU se udržují právě pomocí sofistikovaných mechanismů jako zásada subsidiarity. V konečném důsledku se tak upevňuje postavení národních aktérů vưči supranacionalitě EU, čímž se existenční a funkční otázky EU přesouvají blíže $\mathrm{k}$ jejím občanům. ${ }^{77}$ Další vývoj lze spatřovat zejména $\mathrm{v}$ precizaci zásady subsidiarity vůči novým oblastem (typicky ÚEVŽ) a celkovém posílení kontrolních mechanismů.

Konstituování ÚEVŽ je opředeno voláním po zajištění efektivnější ochrany finančních zájmů EU. Zajištění tohoto požadavku se jeví jako racionálnější i logičtější, tedy i přiměřenější a efektivnější, právě na unijní úrovni. EU by měla skýtat vhodnější zázemí pro naplnění tohoto cíle. To je i argument, o který byla opřena apologeta původního návrhu o ÚEVŽ, na který byla vystavena žlutá karta pro domnělé porušování zásady subsidiarity. Kriticky vzato, je tomu ale skutečně tak? Jedná se skutečně o efektivnější a racionálnější cestu ochrany evropských zájmů a hodnot? Zásada subsidiarity nám v prrípadě přijímání ÚEVŽ odpověděla, že ano. Nicméně, na gnoseologický rezultát si budeme muset počkat podle toho, co ukáže empirická praxe.

73 BŘICHÁČEK, T. Unie blíqká i vzdálená. Praha: Institut Václava Klause, 2014, č. 11, s. 49.

74 Ibid., s. 53.

75 PÍTROVÁ, L. Princip subsidiarity v EU - od virtuální reality k efektivní parlamentní kontrole. In: GEORGIEV, J. (ed.). Princip subsidiarity v právni teorii a praxi. Praha: CEVRO Institut, 2007, s. 106.

76 Výrok předsedy rakouského Ústavního soudu Karla Korineka na konferenci v St. Pöltenu věnující se zásadě subsidiarity během rakouského předsednictví EU v roce 2006.

77 MITSILEGAS, V. EU Criminal Law after Lisbon. Rights, Trust and the Transformation of Justice in Europe. Oxford - Portland - Oregon: Hart Publishing, 2016, s. 40. 